\title{
Assessment of Teaching Performance of Student-teachers on Teaching Practice
}

\author{
James Ayodele Oluwatayo ${ }^{1} \&$ Samuel Olufemi Adebule ${ }^{2}$ \\ ${ }^{1}$ Institute of Education, Ekiti State University, Ado-Ekiti, Nigeria \\ ${ }^{2}$ Faculty of Education, Ekiti State University, Ado-Ekiti, Nigeria \\ Correspondence: James Ayodele Oluwatayo, Institute of Education, Ekiti State University, Ado-Ekiti, Nigeria. \\ Tel: 234-803-396-4547. E-mail: ayotayor@yahoo.com
}

\author{
Received: May 13, 2012 Accepted: May 21, 2012 Online Published: August 8, 2012 \\ doi:10.5539/ies.v5n5p109 URL: http://dx.doi.org/10.5539/ies.v5n5p109
}

\begin{abstract}
The study assessed teaching performance of 222 student-teachers from the Faculty of Education, Ekiti State University, posted to various secondary schools in Ekiti State for a six-week teaching practice during 2010/2011 academic session. The sample included 119 males, 103 females, 78 (300-Level) and 144 (400-Level) students. Data were collected using Teaching Performance Assessment Form designed by the Faculty of Education, Ekiti State University and analysed using frequency counts, percentages, item-total correlations and t-test comparison, tested at 0.05 level of significance. Results showed satisfactory teaching performance of the student-teachers while gender and previous teaching experience had no significant influence on teaching performance of the student-teachers. It was recommended that supervisors (of teaching practice/raters) should be thoroughly trained on the use of assessment instrument for reliable measurement of student-teachers' teaching performance.
\end{abstract}

Keywords: assessment, teaching performance, gender, academic level, teaching practice

\section{Introduction}

The teaching practice is one of the most important aspects of teacher education. It is an exercise designed to expose the student-teachers to the practical aspect of teaching profession and to enable them put into practice the theoretical knowledge acquired during classroom interactions with their lecturers.

At the undergraduate level, the teaching practice is usually done in two phases, each phase spanning through six weeks during which the students are expected to take part in every aspect of school life including teaching, testing, examining, academic societies and co-curricula activities. However, in this study, attention is given to teaching based on six criteria namely, plan of the lesson, the use of teaching aids/devices, conduct of the lesson, knowledge of subject matter, class management and teacher's personality. Expectedly, the teaching performance may be rated poor, fair, good, very good or excellent depending on individual's commitment to the exercise.

Basically, the student-teachers are expected to plan their lessons appropriately. Good planning underpins flexibility and provides the teacher with structure and security (Pollard, 2006). The plan of a lesson includes formulation of concise and feasible learning objectives, organization of content and technical language of instruction. The learning objectives express what the teacher intends that the students learn in terms of skills, knowledge and understanding. As explained by Pollard (2006), learning objectives are the essential planning tools of the teacher, as without clear and concise objectives linked to specific activities, the teacher has little basis on which to define the purpose of a task clearly for the learner or assess learners' progress. However, it is important to note that too many objectives for any one lesson are likely to prevent a clear focus on the core learning that the teacher intends to achieve. More importantly, the content of the lesson needs to be sequentially organized in order to provide instructional steps to be followed by the teacher so that no aspect of the lesson is omitted.

Unarguably, every subject has its own technical language which is bound up with its way of thinking, talking and writing. Indeed, Wells (1986) notes that students learn through language and express their understanding of subject matter in language. It behoves the student-teachers therefore to employ the appropriate language in their lesson plans so that new patterns of thinking and understanding are developed in their students. 
The literature on the use of teaching aids in reinforcing a skill fact or idea in the classroom (e.g. Abdullahi, 1982; Phadke, 2008; Creneti, 2012) has acknowledged that effective use of relevant and quality teaching aids by the teachers helps learners to improve their perceptive skills thus arousing their interest, relieving their anxiety and boredom. In fact, experience shows that students of the present age hardly feel comfortable learning concepts in abstract. They tend to enjoy learning when instructions are given using concrete materials such as charts, models, scientific equipment, video and audio cassettes, radio, television, projectors, multimedia information and communication technology (ICT) resources and others. These various media are means of deepening, enriching and broadening the lesson and providing first-hand experiences that may allow each student to observe and indirectly experience other environment. It is important for the student-teachers to identify and utilize the most appropriate teaching aids to illustrate and clarify the intents of the lesson so that the learners can understand the importance of each concept.

The entire purpose of teaching is to make positive change in students (Ryan \& Couver, 2007). However, the skill of teaching is inherent in individuals which needs to be developed through training and practice. A teacher is presumed to be at his or her best if he or she is able to impart knowledge acquired over the years to produce positive change in behaviour of the learners. However, for a teacher to teach meaningfully demands so much of his or her attention that an essential element in the teaching-learning process is not lost. Essentially, the conduct of any meaningful lesson involves relevant, interesting and imaginative introduction, orderliness of presentation that interest and motivate students and make learning objectives clear to the students. It also involves the use of language and dictions that command respect from the learners, even distribution of quality questions that pose challenges or stimulate the curiosity of the learners. Further, the lesson is expected to involve students' active participation. That is, instruction is to be more student-centred and less teacher-directed (Seweje, 2000) so that students can solve their problems interestingly and share information on various concepts and gain much confidence, skills and competence to perform satisfactorily in the subjects. Moreover, the lesson is expected to entertain variety of instructional techniques (demonstration, discussion, practical exercise, etc), masterly, use of chalkboard for illustration of concepts, meaningful evaluation of learners' achievement, summary of lesson and follow-up assignments.

The study by Alexander, Rose \& Woodhead (1992) emphasise that the knowledge of subject matter is a critical factor at every point in the teaching process: in planning, assessing and diagnosing, task setting, questioning, explaining and giving feedback. Similarly, Appleton (1995) notes that vital attributes of effective teaching include understanding of how students learn and empathy with them. More explicitly, Shulman (1986) identifies three sorts of subject matter, first, content knowledge which refers to knowledge of the subject held by the teacher, second, pedagogic content knowledge which refers to knowledge of how to use content knowledge for teaching purposes, and third, curriculum knowledge which refers to knowledge of curriculum structures and materials, and how to use them effectively in classroom context. Expectedly, the teachers ought to make judgments about the appropriate teaching of knowledge, concepts, skills and attitudes for the realization of the objectives of the lesson. As reported by Watt (1996), there seems to be something of a consensus that teachers with sound knowledge of subject matter are likely to help learners create experiences that actually work to produce learning.

Meanwhile, research in classroom management (e.g. Wang, Haertel \& Walberg, 1993) shows that effective classroom management has the largest effect on students' achievement. Similarly, in a meta-analysis of more than 100 studies, Marzano $\left(2003^{\mathrm{b}}\right)$ finds that the quality of teacher-student relationships is the keystone for all other aspects of classroom management. Adelman \& Taylor (2002) and Dunn \& Baker (2002) agree that effective classroom management entails arrangement of classroom in a way conducive to effective management, alertness to classroom problems, acknowledgement of students' behaviours, reinforcement of acceptable behaviour, provision of negative consequences for unacceptable behaviour, establishment of clear learning goals, taking personal interest in students, exhibition of assertive behaviour by the teacher and awareness of high-needs of students. Indeed, Ferguson (2010) notes that students are likely to engage more deeply and master their lessons more thoroughly when their teachers care about them, control the classroom effectively, clarify complex ideas, challenge them to work hard and think hard, deliver lessons in ways that captivate, confer with them about their ideas and consolidate lessons to make learning coherent. This makes intuitive sense that students can hardly learn in a chaotic and poorly managed classroom. Indirectly, teachers of various categories are enjoined to follow the golden rules of class management so as to achieve the objectives of the lesson and maintain high discipline during teaching-learning process.

Researches in educational studies (e.g. Erdle, Murray \& Rushton, 1985; Maclure, 2000) demonstrate that teacher's personality or self-identity, is intimately concerned with classroom discipline and effective teaching. In 
essence, teacher's personality is likely to promote positive learning or destroy a well-planned lesson. Beyond exaggeration, it is likely that a teacher who presents himself or herself admirably in the class, demonstrates confidence to project and assert self, shows enthusiasm at lessons, maintains emotional stability at all situations, displays amiable mannerism when communicating with the learners and exhibits eagerness to learn, may create stable impression in the hearts of the learners and consequently motivate them to learn and achieve satisfactorily. Conversely, a teacher who appears in the classroom ruffled, uncoordinated and hard of understanding, may scare the learners and destroy the gamut of teaching and learning process.

The practical issue in the foregoing, however centres on the question of whether the student-teachers possess the pedagogical skills to satisfy the criteria measure. Really, the answer is speculative. This is so because some of the student-teachers may find it difficult to enact change from student role to teacher role, especially those who are engaging in teaching for the first time (300-Level students). It may be assumed then that effective practices of the first timers may not be as efficacious as when used by those who had taught previously (400-Level students) or experienced permanent teachers. Moreover, there is a problem of agreement in the rating of teaching performance of student-teachers by the assessors as there may be demerits of leniency or harshness. There is also a further problem concerning the dispositional ability of male and female student-teachers to teaching itself because much of the problem militating against academic quality in Nigerian schools has been attributed to poor teaching (Fijuyigbe, 2011). Nevertheless, it is believed that the outcome of this study would provide concise answer to the question.

\section{Research Questions}

The following questions were raised to guide the study:

1) What is the level of teaching performance of the student-teachers?

2) Is there any correlation between scores on the Teaching Performance Assessment Form (TPAF) and each of the Teaching Performance Assessment (TPA) categories?

3) Is there any difference between teaching performance of male and female student-teachers?

4) Is there any difference between teaching performance of 300-Level and 400-Level student-teachers?

\section{Research Hypotheses}

The following hypotheses were tested at 0.05 level of significance:

$\mathrm{HO}_{1}$ : There is no significant correlation between scores on the TPAF and each of the TPA categories.

$\mathrm{HO}_{2}$ : There is no significant difference between teaching performance of male and female student-teachers.

$\mathrm{HO}_{3}$ : There is no significant difference between teaching performance of 300-Level and 400-Level student-teachers.

\section{Methodology}

\section{Sample}

The participants were drawn from one cohort of undergraduates in the Faculty of Education, Ekiti State University, Ado-Ekiti, posted to various secondary schools in Ekiti State for their mandatory six weeks teaching practice during 2010/2011 academic session. They consisted of 222 student-teachers (male $=119$, female $=103$ ), (300-Level students=78, 400-Level students $=144$ ).

\section{Research Instrument}

The instrument for collecting data was a typical rating scale, titled Teaching Performance Assessment Form (TPAF) designed by the Faculty of Education, Ekiti State University, Ado-Ekiti. TPAF had six categories (CAT) with varied items and scoring weights: CAT 1 -Plan of the lesson (three items $=15 \%$ ); CAT 2-Teaching aids/devices (three items $=15 \%$ ); CAT 3 -Conduct of the lesson (nine items $=45 \%$ ); CAT 4 -Knowledge of the subject matter (one item $=10 \%$ ); CAT 5 -Class management (two items $=10 \%$ ); CAT 6-Teacher's personality (one item=5\%).

Each item in CAT 1, CAT 2, CAT 3, CAT 5 and CAT 6 was rated on a five-point scale namely Excellent $=5$, Very Good $=4$, Good $=3$, Fair $=2$, Poor $=1$. The internal consistency of the instrument was estimated at 0.88 using Cronbach-alpha (1951).

\section{Research Procedure}

Prior to the commencement of the teaching practice exercise, participants were inducted on the importance of teaching practice to teacher education. Emphasis was placed on regular attendance and punctuality in schools, 
active participation in school activities, effective teaching in the classroom and mode of assessment of teaching performance. Participants were allowed to ask questions based on the teaching practice and their expectations during the exercise.

\section{Data Collection and Analysis}

Data were collected using research assistants. They were Master's degree students in Tests and Measurement, Faculty of Education, Ekiti State University, Ado-Ekiti whose course work included classroom observational techniques. They were assigned to objectively observe and rate teaching performance of each student-teacher twice $\left(3^{\text {rd }}\right.$ and $5^{\text {th }}$ weeks of six weeks). The average score for each participant was computed and presented for analysis. Data were analysed using frequency counts, percentages, item-total correlation and t-test statistics tested at 0.05 level of significance.

\section{Results}

Question 1: What is the level of teaching performance of the student-teachers?

Data were analysed using frequency counts and percentages as presented in table 1.

Table 1. Frequency counts and percentages of teaching performance of student-teachers

\begin{tabular}{llll}
\hline Level & Range of scores & $\mathbf{N}$ & $\mathbf{\%}$ \\
\hline Excellent & $70^{+}$ & 08 & 3.6 \\
Very Good & $60-69$ & 101 & 45.5 \\
Good & $50-59$ & 113 & 50.9 \\
Fair & $45-49$ & 0 & 0.00 \\
Poor & $40-44$ & 0 & 0.00 \\
Total & & 222 & 100.00 \\
\hline
\end{tabular}

Table 1 shows that 8 participants representing 3.6\% had excellent teaching performance, 101 participants representing $45.5 \%$ had very good teaching performance, 113 participants representing $50.9 \%$ had good teaching performance, while no participant had fair or poor teaching performance. These results show that the participants had either good, very good or excellent teaching performance.

\subsection{Testing of Hypotheses}

$\mathrm{HO}_{1}$ : There is no significant correlation between scores on the TPAF and each of the TPA categories

Data were analysed using item-total correlation to determine the degree of agreement of the raters on teaching performance of the student-teachers. The outcome of analysis is as presented in table 2 .

Table 2. Correlation between scores on TPAF and TPA categories

\begin{tabular}{ll}
\hline Categories & Correlation \\
\hline CAT 1 & $0.464 *$ \\
CAT 2 & $0.325 *$ \\
CAT 3 & $0.427 *$ \\
CAT 4 & $0.511 *$ \\
CAT 5 & $0.412 *$ \\
CAT 6 & $0.531 *$ \\
\hline
\end{tabular}

$\mathrm{N}=222, \mathrm{P}^{*}<0.05$ (significant results)

Table 2 shows that correlations between scores on TPAF and CAT 1, CAT 2, CAT 3, CAT 4, CAT 5, CAT 6 were $0.464,0.325,0.427,0.511,0.412$ and 0.531 respectively. All correlation coefficients were marginally significant, indicating that the rating of teaching performance of the student-teachers had marginal agreement or marginally homogenous. 
$\mathrm{HO}_{2}$ : There is no significant difference between teaching performance of male and female student-teachers

Data were analysed using t-test comparison as presented in table 3.

Table 3. T-test comparison between teaching performance of male and female student-teachers

\begin{tabular}{llllll}
\hline Variables & $\mathbf{N}$ & Mean & SD & df & $\mathbf{t}_{\text {cal }}$ \\
\hline Male & 119 & 64.3 & 9.34 & & \\
Female & 103 & 62.7 & 8.17 & 220 & 1.16 \\
\hline
\end{tabular}

$\mathrm{p}>0.05$ (not significant)

Table 3 shows that the mean teaching performance of males and female were 64.3 and 62.7 while their corresponding standard deviations were 9.34 and 8.17 respectively. That is, the scores of males ranged from approximately 55 to 74 while females ranged from 55 to 71 . The t-calculated was 1.16 while its corresponding table value at 0.05 level of significance was 1.96. Since $t_{\text {cal }}<t_{\text {tab }}$, it implies no significant difference between teaching performance of male and female student-teachers.

$\mathrm{HO}_{3}$ : There is no significant difference between teaching performance of 300-Level and 400-Level student-teachers.

Data were analysed using t-test comparison as presented in table 4.

Table 4. T-test comparison between teaching performance of 300-Level and 400-Level student-teachers

\begin{tabular}{llllll}
\hline Variables & $\mathbf{N}$ & Mean & SD & df & $\mathbf{t}_{\text {cal }}$ \\
\hline 400 & 144 & 61.2 & 9.14 & & \\
300 & 78 & 60.9 & 8.71 & 220 & 0.193 \\
\hline
\end{tabular}

$\mathrm{p}>0.05$ (not significant)

Table 4 shows that the mean teaching performance of 400-Level and 300-Level student-teachers were 61.2 and 60.9 while their corresponding standard deviations were 9.14 and 8.71 respectively. That is, the scores of 300 -Level ranged from approximately 52 to 69 while that of 400-Level ranged from 51 to 70 . The t-calculated was 0.193 while its corresponding table value at 0.05 level of significance was 1.96 . Since $\mathrm{t}_{\mathrm{cal}}<\mathrm{t}_{\mathrm{tab}}$, it implies that no significant difference existed between teaching performance of 300-Level and 400-Level student-teachers.

\section{Discussion}

The focus in this study was to assess the teaching performance of student-teachers on a six-week teaching practice. Interestingly, the results in table 1 showed favourable teaching performance as participants were rated as either good, very good or excellent. The reason might be connected with the fact that the student-teachers were formally inducted on the importance of teaching practice to teacher education which might have led to their strict adherence to the pedagogical principles of effective teaching. More importantly, the results in table 2 affirmed the reliability of rating accorded the teaching performance of the student-teachers as correlation coefficient in each category of teaching performance assessment was positive and significant. By usual rule of thumb for item-total correlation (Kline, 1986; Streiner \& Norman, 2003; Bowling, 2009), items should correlate with the total scale score by more than 0.20 to satisfy reliability and scaling assumptions. A re-examination of table 2 showed that all correlation coefficients were above 0.20 signifying that the scores derived from the measuring instrument were reliable and hence the teaching performance of the student-teachers was reliable.

The results in table 3 showed that there was no significant difference between teaching performance of male and female student-teachers. This finding is logical in the sense that the participants were drawn from one-cohort of undergraduates in the Faculty of Education, in one university with similar exposure to pedagogical experiences resulting to similarity in the range of scores. Moreover, similar study in this area, Ohikena \& Anam (1994) did not find any significant difference in teaching effectiveness of males and females in secondary education in Nigeria. This implies that gender or sex of the student-teachers had no significant influence on their teaching performance. 
The results in table 4 showed no significant difference between teaching performance of 300-Level and 400-Level student-teachers as t-calculated was less than the t-table. Moreover, the spread of scores was similar. This result is surprising. Ordinarily, one would expect the 400-Level student-teachers to have higher teaching performance than their 300-Level counterparts because of the former's previous exposure to teaching practice which might have provided them with higher experience but contrary was the case. This indicates that previous experience of teaching has no significant influence on teaching performance of the student-teachers. However, some student-teachers may fall into the categories of people described as 'born teachers' who start from the outset to teach distinctively (Desforges, 1995; Bressoax, 1996).

\section{Conclusion}

It could be concluded in this study that the teaching performance of the student-teachers was satisfactory and that gender and previous teaching experience of student-teachers had no significant influence on their teaching performance.

\section{Recommendations}

Based on the findings, the following recommendations were made:

1) Stakeholders in teaching practice in colleges of education and universities should formally induct their student-teachers on the importance of the exercise to teacher education to ensure satisfactory teaching performance of the students.

2) The supervisors of the student-teachers should be trained on the effective use of Teaching Performance Assessment Form in order to obtain reliable assessment scores.

3) The cooperative teachers in respective subjects in various secondary schools should be allowed to separately assess the student-teachers for comparability of standard in scoring.

4) The teaching practice must be thoroughly monitored to ensure total compliance with the principles guiding the exercise.

\section{References}

Abdullahi, A. (1982). Science teaching in Nigeria. Ilorin: Atoto Press Ltd.

Adelman, H. S., \& Taylor, L. (2002). School counsellors and school reform: New directopms. Professional School Counselling, 5(4), 235-248.

Alexander, R. J., Rose, J., \& Woodhead, C. (1992). Curriculum organisation and classroom practice in primary schools. A discussion paper. London: Department of Education and Science; paragraph 77.

Appleton, K. (1995). Student teachers' confidence to teach science in more scientific knowledge necessary to improve self-confidence. International Journal of Science Education, 17(3), 367-369. http://dx.doi.org/10.1080/0950069950170307

Bowling, A. (2009). Research methods in health. Investigating health and health services ( $3^{\text {rd }}$ edition). London: McGraw-Hill, Open University Press.

Bressoax, P. (1996). The effect of teacher training on pupils' achievement: The case of elementary schools in France. School Effectiveness and School Improvement, 7(3), 252-279. http://dx.doi.org/10.1080/0924345960070303

Creneti, J. (2012). Types of teaching aids. Retrieved from http://www.ehow.com. 1999-2012.

Cronbach, L. J. (1951). Coefficient alpha and the internal structure of test. Psychometrika, 16, 297-334. http://dx.doi.org/10.1007/BF02310555

Desforges, C. (1995). 'How does experience affect theoretical knowledge for teaching?' Learning and Instruction, 5, 385-400.

Dunn, N. A., \& Baker, S. B. (2002). Readiness to serve students with disabilities: A survey of elementary school counsellors. Professional School Counsellors, 5(4), 277-284.

Erdle, S., Murray, H. G., \& Rushton, C. (1985). Personality, classroom behaviour and college teaching

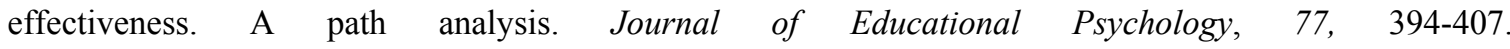
http://dx.doi.org/10.1037/0022-0663.77.4.394

Ferguson, R. F. (2010). Student perception of teaching effectiveness. National Centre for Teacher Effectiveness on the Achievement Gap and Value. Harvard University. Retrieved from www.gscharvard/edu 
Fijuyigbe, K. T. (2011). Effects of activity based and inquiry methods on attitude and performance in computer science among junior secondary school students in Ekiti State. Unpublished M.Ed. thesis, Ekiti State University.

Kline, P. (1986). A handbook of test construction. London: Methuen.

Maclure, M. (2000). Arguing for yourself: Identity as an organising principle in teachers' jobs and lives. British Educational Research Journal, 19(4), 311-322. http://dx.doi.org/10.1080/0141192930190401

Marzano, R. J. (2003b). Classroom management that works. Alexandria VA: ASCD.

Phadke, S. (2008). Computer-based teaching learning aids in science class. Retrieved April 2012 from http://www.digitallearning

Pollard, A. (2006). Reflective teaching. $2^{\text {nd }}$ edition. London: British Library.

Ryan, K., \& Cooper, J. M. (2007). Kaleidoscope readings in education. $11^{\text {th }}$ edition. New York: Houghton Mifflin Company. Chapter, 53, 318-319.

Seweje, R. O. (2000). The challenge of science teaching in Nigeria today. Journal of Educational Foundations, $1(1), 208-220$.

Shulman, L. S. (1986). Those who understand knowledge growth in teaching educational research, 15, 1-14.

Streiner, G. I., \& Norman, D. R. (2003). Health measurement scales: A guide to their development and use. $3^{\text {rd }}$ edition. Oxford: Oxford University Press.

Wang, M. C., Haertel, G. D., \& Walberg, H. J. (1993). Toward a knowledge base for school learning. Review of Educational Research, 63(3), 249-294.

Watt, D. (1996). An analysis of teacher questioning behaviour in constructionist primary science education. International Journal of Science Education, 18(5), 601-613. http://dx.doi.org/10.1080/0950069960180508

Wells, G. (1986). The meaning makers: Children learning language and using language to learn. London: Hodder and Stoughton. 